\title{
EVALUATION OF DIFFERENT STRATEGIES FOR INDUCTION OF CHILLING TOLERANCE IN SPRING MAIZE USING MORINGA LEAF EXTRACTS
}

\author{
M.B. JUNAID ${ }^{1 *}$, A.A. ALDERFASI ${ }^{1}$, I. AFZAL ${ }^{2}$, H.A. WAJID ${ }^{1, *}$, A. MAHMOOD ${ }^{3}$ \\ *E-mail: abdulwajid2024@gmail.com
}

Received: Sept. 16, 2019. Revised: Nov. 02, 2019. Accepted: Nov. 11, 2019. Published online: Dec. 20, 2019

\begin{abstract}
Spring maize is highly sensitive to low temperatures during the early development of seedlings and to high temperatures during its reproductive stage. Different strategies are being used to minimize the adverse effects of temperature extremes. Therefore, a field experiment was conducted to enhance the performance of spring hybrid maize by seed priming ( $3 \%$ MLE) and transplanting 20 and 30-day-old seedlings. Seed priming with moringa leaf extract (MLE) significantly enhanced stand establishment in both direct sowing and in transplanting, as indicated by the higher emergence percentage, emergence index, and lower time taken to start of emergence and mean emergence time. Minimum days from sowing to tasseling and silking were found in MLE primed 20-day-old seedlings grown in a nursery. However, all the agronomic parameters increased considerably with MLE priming of 20-day-old seedlings. Thus, MLE
\end{abstract}

priming reduced chilling damage by improving stand establishment, whereas transplanting 20-day-old seedlings further enhanced the agronomic traits, yield, and quality of maize. However, the performance of maize plants from 30-day-old transplanted seedling and direct sowing was substandard.

Keywords: nursery raising; early plantation; transplantation; direct sowing.

\section{INTRODUCTION}

Maize (Zea mays L.) is a highyielding cereal and is highly ranked globally with the ability to grow in diverse climates. Among coarse grains, the world production of maize accounts for $77 \%$, and is used for food, feed, and industrial purposes. In countries like Pakistan, where food demand is increasing constantly,

\footnotetext{
${ }^{1}$ Department of Plant Production, College of Food and Agriculture Sciences, King Saud University Riyadh, Saudi Arabia

${ }^{2}$ Department of Crop Physiology, University of Agriculture Faisalabad, Pakistan

${ }^{3}$ National Engineering and Technology Center for Information Agriculture (NETCIA), Nanjing Agricultural University, Nanjing, China
} 
maize plays an important role in cereal food supply. In Pakistan, maize is grown during spring and kharif. In recent past, $30-35 \%$ and $12-15 \%$ of the total annual maize production occurred during kharif and spring, respectively. Annual increases $(20-25 \%)$ in maize growing areas during spring have been observed; this mainly because of very good yields $\left(6-7 \mathrm{t} \mathrm{ha}^{-1}\right)$. Due to resource unavailability and mismanagement and non-adaptation of new technology by the farming community, the genetic potential of yield for all domestic and hybrid cultivars is not achieved. Suboptimal temperatures and low soil moisture content differentially affect germination and post-germination processes. Early sowing of maize can be adopted to avoid this high temperature stress during the flowering stage (Abedullah et al., 2009).

Low soil temperature is the most important hindrance to spring sowing (Afzal et al., 2008). It also causes reductions in leaf size, stem extension, root proliferation, disturbs plant water relations, and inhibits nutrient uptake. Maize is a chillingsensitive crop, which causes increased reactive oxygen species (ROS) and expression of antioxidants (Farooq et al., 2008a, 2008b), reduced mineral and water uptake, stomatal conductance (Aroca et al., 2003), photosynthesis rate (Foyer et al., 2002; Aroca et al., 2003), and ultimately reduced plant growth rate and leaf elongation (Verheul et al., 1995; Sowinski et al., 2005). In maize, chilling stress tolerance can be managed by means of developing chilling tolerant genotypes through breeding and genomic methods.

Agronomic techniques including the application of growth hormones and osmoprotectants to seeds or plants, and early vigor are also useful in inducing chilling stress tolerance (Farooq et al., 2009). Different methods are being used to improve the devastating effects of this suboptimal temperature stress upon emergence and stand establishment of spring maize. These techniques include early sowing (Bakhtavar et al., 2015), nursery growing of spring maize and subsequent transplant to the field (Badran, 2001), and different seed treatment techniques, like seed priming for improving stand establishment and yield performance under normal, as well as stressed conditions (Afzal et al., 2008, 2012).

Seed priming is used to reduce emergence time, harmonize germination, and enhance germination rate and crop establishment in a lot of horticultural (Bradford, 1986), as well as field crops, like wheat, rice, and maize (Afzal et al., 2002; Ghiyasi et al., 2008; Farooq et al., 2008a; Rehman et al., 2011). Nevertheless, it is vital to induce stress resistance in plants, as this increases the potential yield and geographical distribution of crops (Janowiak et al., 2003; Gai et al., 2008).

In the scientific community, Moringa oleifera has a greater attraction because of its plant growth regulators (PGRs) and because it is 
economical, natural, and an environmentally friendly source. Moringa is a tropical tree that is wellknown for its nutritional and medicinal properties (Jahn, 1989). Moringa leaves are the best source of zeatin, cytokinin, ascorbate, potassium, calcium, protein, and vitamin A and C (Foidl et al., 2001). In moringa leaf extracts (MLE), the most active substance is zeatin, a plant hormone from the cytokinine family (Foidl et al., 2001). Cytokinins are plant hormones regulating cell division and a range of developmental events, such as bud formation, leaf expansion, senescence, seed germination, and chloroplast formation (Mok, 1994). Trans-zeatin is a major and ubiquitous cytokinin in maize. Maize leaf extracts can be used as a growth promoter to minimize the harmful effects of stress on maize by delaying leaf senescence and scavenging reactive oxygen species (ROS) (Grossman and Leshem, 1978). Moringa oleifera has a considerable amount of calcium bound in the leaves and stems as calcium oxalate crystals (Olson and Carlquist, 2001).

Transplantation techniques for maize help farmers to harvest a third crop in areas where none would have been possible because of late harvest of Rabi maize, as maize transplantation shortens the crop period (Basu et al. 2003). Directly seeded maize is an alternative method for transplanting maize seedlings raised under cover in a nursery. Under late planting conditions, transplanting of maize may be a possible alternative to direct sowing (Badran, 2001). To avoid high temperatures during the reproductive phase, as it affects pollination and seed setting resulting in reduced grain filling and consequently lowering the final yield (Afzal et al., 2008). The transplantation of maize seedlings into the field is a suitable alternative to directly seeded maize. In case of late planting conditions, transplanting of maize may be a possible alternative to direct sowing (Badran, 2001). Thus, the purpose of this study is to improve chilling tolerance in spring maize by transplanting and to determine the role of seed priming in improving chilling tolerance of spring maize.

\section{MATERIAL AND METHODS}

\section{Experimental site and seed material}

The maize hybrid seed "DATA2236" (Zea mays L.), obtained from Data Agro seeds (Pvt) Ltd., Pakistan, was used as the experimental material. Initial germination percentage and seed moisture content were $95 \%$ and $12 \%$, respectively. A field study was conducted at the agronomic Research Area, University of Agriculture, Faisalabad Pakistan during Spring 2013. The experiment was laid out in a randomized complete block design with split plot arrangement and three replications. Primed and non-primed seeds were kept in the main plot, whereas transplanting treatments were kept in the sub plot. The net plot size was $6 \times 3 \mathrm{~m}$ and plant spacing was maintained at $75 \times 25 \mathrm{~cm}$.

\section{Seed priming protocol}

Maize seeds were soaked in a solution of $3 \%$ MLE for $24 \mathrm{hrs}$ for 
priming. During priming, a seed weight to solution volume ratio $\mathrm{I}: 10(\mathrm{w} / \mathrm{v})$ was maintained. Subsequently, seeds were washed carefully with distilled water and dried back to their original moisture level under shade (Lee and Kim, 2000). Dry seeds were used for raising primed nurseries and direct planting. Untreated dry seeds were used as the control and raised control nursery.

\section{Nursery raising}

In the greenhouse, 20 and 30-day-old nurseries with primed and non-primed (control) seeds were raised in sand (height - 4 inch). The plants were watered daily or as and when required depending upon the depletion of moisture contents. After 20 and 30 days, the plants in the nursery were transplanted, the control was planted directly, and the primed seeds were sown on ridges in the field simultaneously.

\section{Crop husbandry}

A seedbed was prepared by cultivating the soil 2-3 times with tractor mounted cultivators each followed by planking. Maize seeds were sown on Jan. 15, 2013, with the help of dibblers on the ridge. The seed rate used was $25 \mathrm{~kg} / \mathrm{ha}$ and fertilizer were applied at the rate of 200-115 kg NP ha ${ }^{-1}$.

The fertilizer was applied in such a way that half of the $\mathrm{P}$ were applied at sowing time in the form of urea and diammonium phosphate (DAP), while the rest of the nitrogen was applied when the plants were knee height. The first irrigation was applied one week after sowing and six irrigations were applied to mature the crop. Thinning was done when the crop attained a height of $15-20 \mathrm{~cm}$ to maintain interplant spacing. For the control of maize insects, such as the maize borer and shoot fly, Furadon was applied@20 kg ha ${ }^{-1}$. To avoid competition between weeds and crops, weeds were controlled in the crop field by hoeing twice.

The following observations were recorded during the course of the study.

\section{Stand establishment}

The experimental site was visited daily. The number of emerged seeds was recorded daily according to the seedling evaluation. Ellis and Roberts (1981) equation was used to calculate mean emergence time (MET). Emergence index (EI) was calculated according to the handbook of the Association of Official Seed Analysts (1983). The final emergence percentage was recorded at the end of the experiment; it represents the ratio, in percentage, of the final number of emerged seedlings to total seeds planted.

\section{Phenology and allometry}

Ten plants were selected at random in each plot and tagged for recording days to $50 \%$ tasseling and days to $50 \%$ silking. The average number of days taken to $50 \%$ tasseling was calculated from the date of sowing. Ten plants were selected at random in each plot and tagged to record the number of leaves per plant, days taken to physiological maturity, from emergence to anthesis, anthesis to silking, and silking to maturity.

For growth analysis, the first sampling was done 45 days after sowing and three harvests were conducted at 15-day intervals. Two plants were harvested at random from each plot immediately after which their fresh weight was recorded. A sample of $50 \mathrm{~g}$ containing both leaves and stems was oven dried to measure the dry weight of plants. Total dry weight was worked out from total fresh weight using the unit method. For leaf area measurements, $10 \mathrm{~g}$ leaf samples were taken, and leaf area was 
measured using the leaf area meter (Model: CI 203). Whole plant leaf area was determined using the total leaf weight of the plant with the unit method. Sampling was carried out four times at 15-day intervals. Following sampling, leaf area, fresh and dry weights, leaf area index (Watson, 1947), and crop growth rate (Hunt, 1978) were calculated.

\section{Agronomic and yield attributes}

Eight plants from each plot were selected at random and their agronomic and yield attributes were determined. All the cobs from each net plot were separated from plants and shelled using a Sheller and weighed to determine grain yield. Subsequently, the yield was converted into $\mathrm{t} \mathrm{ha}^{-1}$.

\section{Grain quality attributes}

Fine ground maize grain material (2 g) was collected in a Kjeldahl flask along with $10 \mathrm{ml}$ of concentrated $\mathrm{H}_{2} \mathrm{SO}_{4}$ and $2 \mathrm{~g}$ of digestion mixture. The resulting mixture was then heated for three hours, then the volume was made up to $250 \mathrm{ml}$ with distilled water.

For distillation, $50 \mathrm{ml}$ of digested mixture was transferred to a distillation chamber. Into Erlenmeyer flasks with the indicator pre-marked to specify a $15-\mathrm{ml}$ volume, $5 \mathrm{ml}$ of $2 \%$ boric acid solution was added. To the flasks, 2-3 drops of methyl red indicator was added, and they were placed under the condenser of the distillation chamber to start the distillation process.

The ammonia liberated during this process reacted with water and was converted into ammonium hydro-oxide, which was collected in the receiver. The ammonium was absorbed in the form of ammonium borate (pink to yellow color). The "distill" was titrated against a standard acid $(0.1 \mathrm{~N} \mathrm{HC1})$ till the yellow to pink end point.
Dried seeds of each experimental unit were crushed and fed to the Soxhlet extractor fitted with a $1 \mathrm{~L}$ round bottom flask and a condenser. The extraction was executed with $0.5 \mathrm{~L}$ of $\mathrm{n}$-Hexane on a water bath for 6-7 hrs. The solvent was distilled off under vacuum $m$, a rotatory evaporator, and the oil percentage was recorded.

\section{Weather data}

The daily fluctuation in average temperature during the whole crop growth period for early and optimal sowing of spring maize under climatic conditions of Faisalabad is shown in Fig. 1.

\section{Statistical analysis}

The collected data were analyzed using the Fisher analysis of variance technique (Steel et al., 1997) and significant treatment means were compared using the least significant difference (LSD) test at a 0.05 probability level.

\section{RESULTS AND DISCUSSION}

\section{Stand establishment}

This study revealed that chilling stress increased mean emergence time and reduced final emergence percentage in nursery grown seedlings, whereas final emergence percentage increased, and mean emergence time decreased in direct seeds primed with moringa leaf extract (MLE). Seedlings which show lower values of mean emergence time (MET) are considered to have higher vigor. Maximum mean emergence time was determined for control primed seeds and was found to be statistically similar to 30-day-old nonprimed seedlings; furthermore, 
minimum mean emergence time of control non-primed seeds was not significantly different from that of 20-old-day non-primed seeds (Figs. 2 and 3).

Seeds that take less time to emerge are considered healthy as this ultimately increases stand establishment. The 20-day-old nonprimed seedlings had the longest emergence time, while the control primed seeds, which were statistically similar to the 30-day primed seedlings, had the shortest emergence time (Fig. 4). Therefore, a higher emergence index value indicates higher seed vigor. Maximum emergence index was accomplished under 30-day-old primed seedlings, which was statistically similar to that in 30-day-old non-primed seedlings, 20-day-old non-primed seedlings, and control non-primed seed controls. The minimum emergence index was observed under non-primed seed controls (Fig. 5).

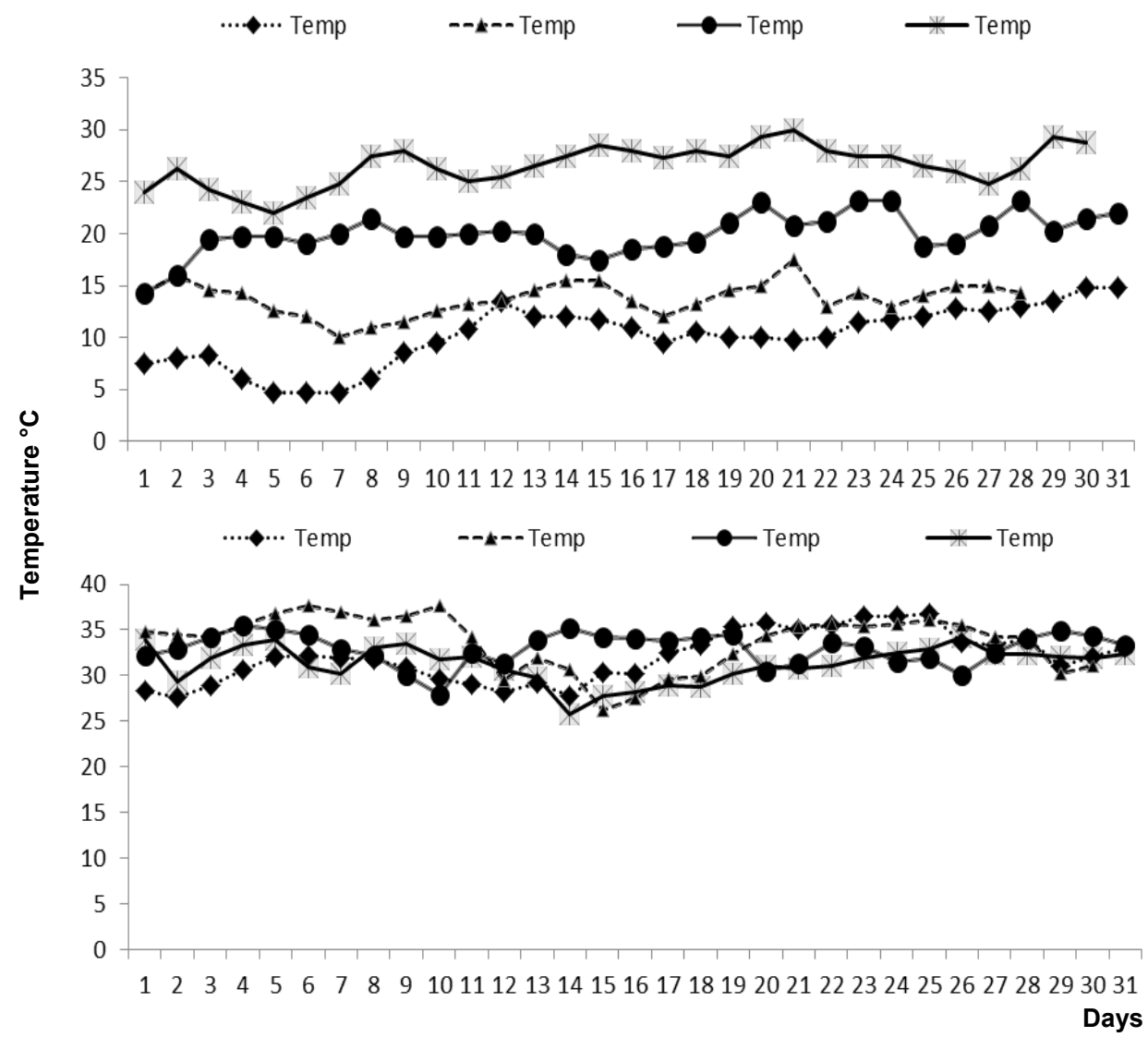

Figure 1 - The daily fluctuations in average temperature during whole crop growth periods of spring maize hybrid DATA-2236 


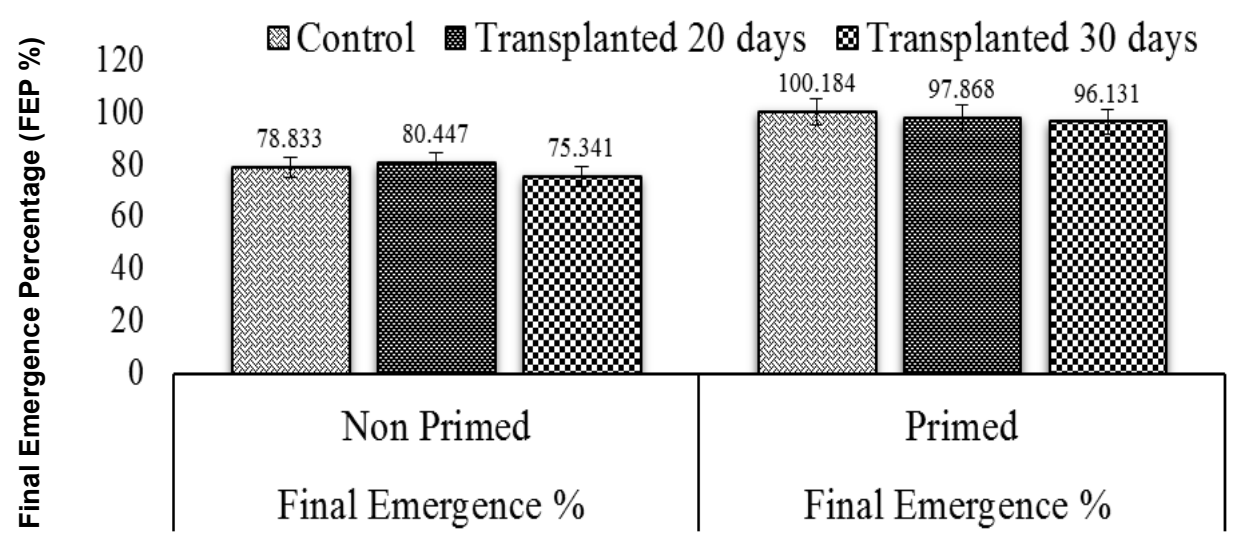

Figure 2 - Effects of different seed invigoration techniques on final emergence percentage (FEP)

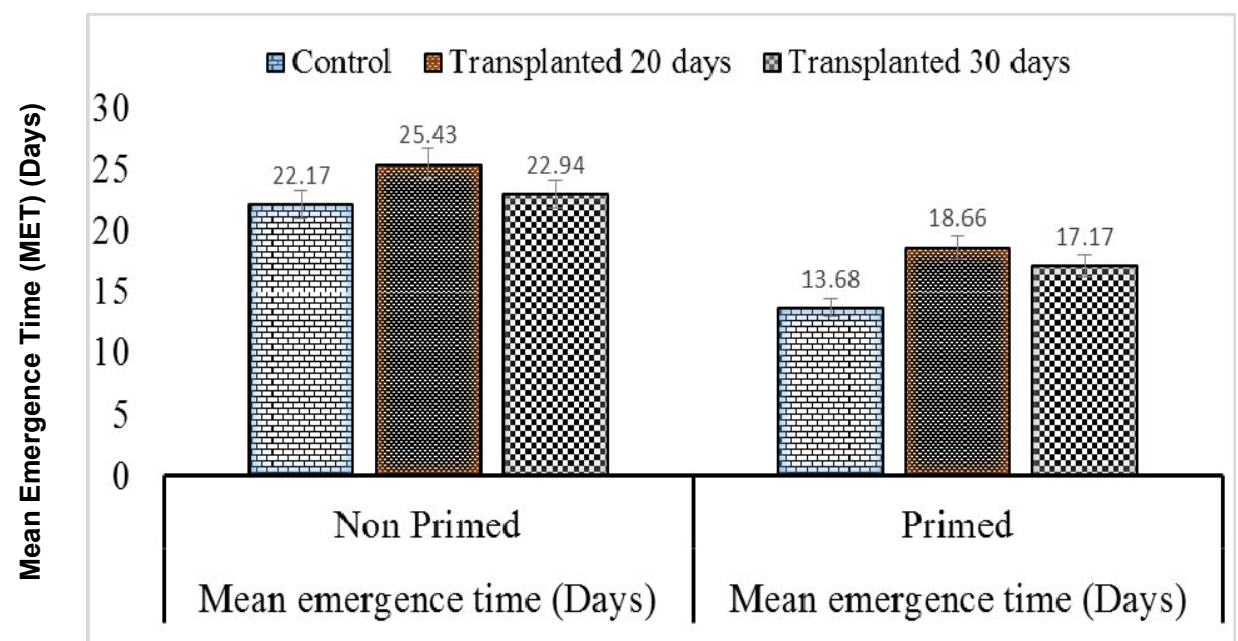

Figure 3 - Effects of different seed invigoration techniques on mean emergence time (MET)

\section{Phenology and allometry}

The number of leaves per plant is often used as a marker of the size of the assimilatory system of a crop. The effect of treatments and blocks and the interaction between treatments and blocks were significant (Table 1). Plants reached their maximum number of leaves under 30 days in primed transplanted seedlings
(Table 1). The minimum number of leaves per plant was found in the nonprimed seedling controls. Treatments for days taken to $50 \%$ tasseling were non-significant, while the main effect of blocks and the interaction between blocks and treatments was significant (Table 1). The maximum days taken to $50 \%$ tasseling was determined for primed seedling controls, followed by 
20-day-old primed transplanted The days taken to $50 \%$ silking seedlings. The minimum days taken to treatments were non-significant, while $50 \%$ tasseling was recorded for the main effects of blocks and the 30-day-old non-primed transplanted seedlings, followed by 20-day-old interaction between blocks and non-primed transplanted seedlings.

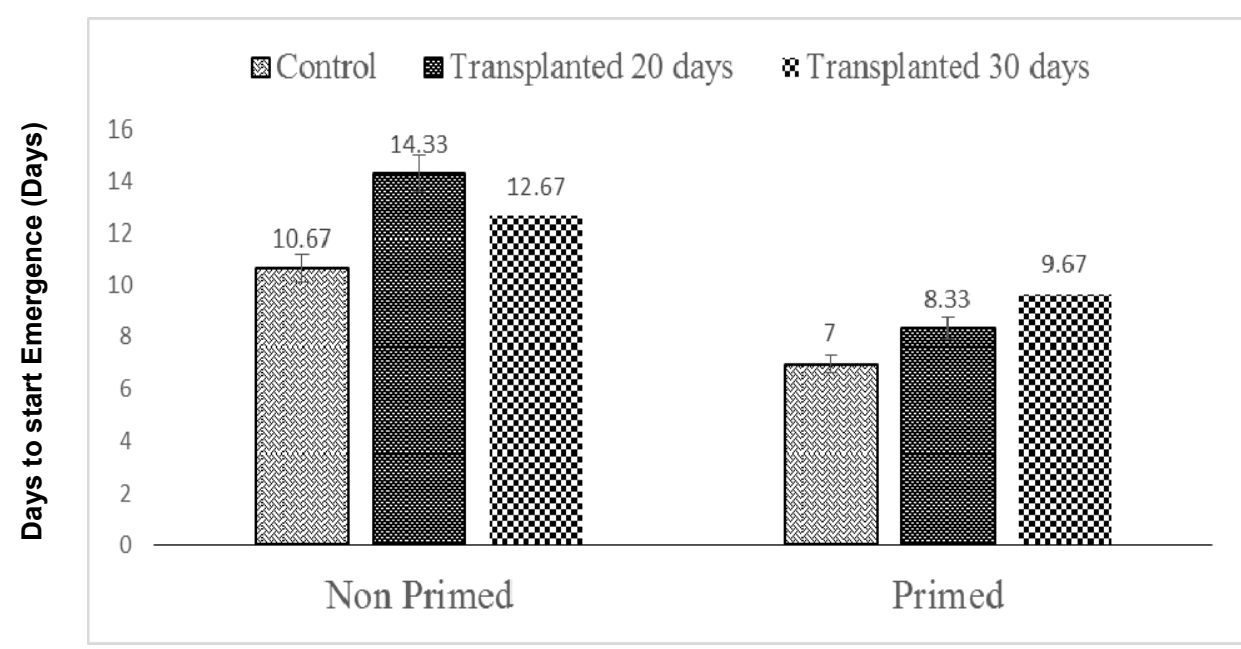

Figure 4 - Effects of different seed invigoration techniques on days to start of emergence

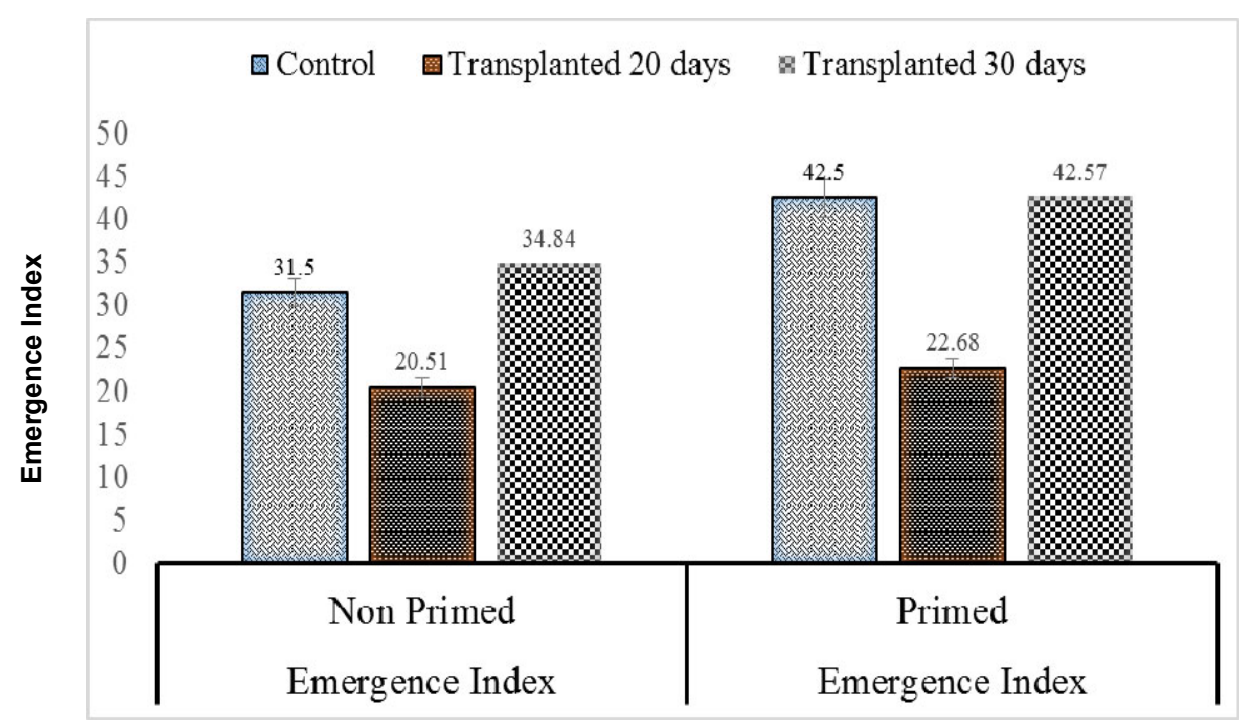

Figure 5 - Effects of different seed invigoration techniques on emergence index 
Table 1 - Effects of different seed invigoration techniques on phenology and allometry

\begin{tabular}{cccccc}
\hline \multicolumn{2}{c}{ Treatments } & $\begin{array}{c}\text { No. of } \\
\text { leaves } \\
\text { per plant }\end{array}$ & $\begin{array}{c}\text { Days to } \\
\mathbf{5 0 \%} \\
\text { tasseling }\end{array}$ & $\begin{array}{c}\text { Days to } \\
\mathbf{5 0 \%} \\
\text { silking }\end{array}$ & $\begin{array}{c}\text { Days to } \\
\text { physiological } \\
\text { maturity }\end{array}$ \\
\hline \multirow{3}{*}{ Non-prime } & Control & $14.7 \mathrm{c}$ & $71.80 \mathrm{abc}$ & $76.68 \mathrm{abc}$ & $90.68 \mathrm{bc}$ \\
\cline { 2 - 6 } & $\mathbf{2 0}$ days nursery & $15.3 \mathrm{c}$ & $68.94 \mathrm{bc}$ & $74.09 \mathrm{bc}$ & $88.42 \mathrm{c}$ \\
\cline { 2 - 6 } & $\mathbf{3 0}$ days nursery & $15.0 \mathrm{c}$ & $67.87 \mathrm{c}$ & $73.02 \mathrm{c}$ & $86.68 \mathrm{c}$ \\
\hline \multirow{3}{*}{ Prime } & Control & $18.0 \mathrm{~b}$ & $77.67 \mathrm{a}$ & $83.22 \mathrm{a}$ & $98.55 \mathrm{a}$ \\
\cline { 2 - 6 } & $\mathbf{2 0}$ days nursery & $18.0 \mathrm{~b}$ & $76.11 \mathrm{ab}$ & $81.44 \mathrm{ab}$ & $96.78 \mathrm{ab}$ \\
\cline { 2 - 6 } & $\mathbf{3 0}$ days nursery & $19.3 \mathrm{a}$ & $75.00 \mathrm{abc}$ & $80.33 \mathrm{abc}$ & $95.67 \mathrm{ab}$ \\
\hline \multirow{2}{*}{ LSD interaction at $\mathbf{p} \mathbf{0 . 0 5}$} & 5.2 & 6.38 & 6.51 & 6.36 \\
\hline
\end{tabular}

The data in this study expound that the maximum days taken to $50 \%$ silking was found in primed seedling controls, whereas 30-day-old nonprimed transplanted seedlings took the minimum number of days to $50 \%$ silking (Table 1). Here the effect of blocks and the interaction between blocks and treatments on days taken to physiological maturity were significant, while the effect of treatments was non-significant. We found that the maximum number of days taken to physiological maturity was in primed seedling controls, which was statistically like the 20 and 30-day-old primed transplanted seedlings. The 30-day-old non-primed transplanted seedlings, like the 20-day-old non-primed transplanted seedlings, took the minimum amount of time to reach physiological maturity (Table 1).

Leaf area index (LAI) was used as a marker for the size of the assimilatory system of a crop, leaf area density (LAD) was estimated to examine the importance of photosynthetic area from emergence to maturity (growth), and crop growth rate (CGR) expressed the rate of dry matter accumulation. We found that both primed and non-primed 20-dayold seedlings performed better than all other treatments, and in this study LAI, LAD, and CGR reached their maximum levels in the 20-day-old primed and non-primed seedlings (Figs. 6, 7 and 8).

The effect of treatments and blocks on days taken from emergence to anthesis and anthesis to silking and the interaction between treatments and blocks was significant, whereas the effect of treatments and blocks and their interaction for days taken from silking to maturity were nonsignificant (Table 2). The maximum days taken from emergence to anthesis and anthesis to silking in non-primed 20-day-old seedlings was statistically like that of non-primed controls and 30-day-old non-primed seedlings (Table 2). The minimum number of days taken from both emergences to anthesis and anthesis to 
silking was recorded in 20-day-old primed seedlings, which was statistically like both primed treatments of the control and 30-dayold seedlings (Table 2).

\section{Agronomical and yield attributes}

The number of grains per cob, rows of grains per cob, and cobs per plant directly affects cob weight, and grain and stover yield, respectively. This study explicates that the effect of treatments and blocks on plant height, cob diameter, number of grains per cob, and number of cobs per plant were significant, while the number of rows of grains per cob was nonsignificant. Therefore, among interactions between treatments and blocks, plant height and number of rows of grains per cob was significant, whereas cob diameter, number of grains per cob and number of cobs per plant were non-significant (Table 3). Maximum plant height, cob diameter, number of grains per cob, and number of rows of grains per cob were attained from 20-day-old primed seedlings, while minimum plant height, cob diameter, number of grains per cob, and number of rows of grains per cob were attained from all three non-primed treatments. There was no effect of treatments and blocks on number of cobs per plant (Table 3).

Table 2 - Effect of different seed invigoration techniques on phenology and allometry

\begin{tabular}{ccccc}
\hline \multirow{2}{*}{ Treatments } & $\begin{array}{c}\text { Time from } \\
\text { emergence to } \\
\text { anthesis (days) }\end{array}$ & $\begin{array}{c}\text { Time from } \\
\text { anthesis to } \\
\text { silking (days) }\end{array}$ & $\begin{array}{c}\text { Time from } \\
\text { silking to } \\
\text { maturity } \\
\text { (days) }\end{array}$ \\
\hline \multirow{3}{*}{ Non-prime } & Control & $51.76 \mathrm{ab}$ & $38.84 \mathrm{a}$ & 15.00 \\
\cline { 2 - 5 } & $\mathbf{2 0}$ days nursery & $57.87 \mathrm{a}$ & $39.98 \mathrm{a}$ & 15.33 \\
\cline { 2 - 5 } Prime days nursery & $51.94 \mathrm{ab}$ & $37.86 \mathrm{a}$ & 18.66 \\
\cline { 2 - 5 } & $\mathbf{3 0}$ Control & $47.36 \mathrm{~b}$ & $29.89 \mathrm{ab}$ & 15.66 \\
\cline { 2 - 5 } & $\mathbf{2 0}$ days Nursery & $43.59 \mathrm{~b}$ & $24.56 \mathrm{~b}$ & 16.00 \\
\cline { 2 - 5 } & $\mathbf{3 0}$ days nursery & $46.76 \mathrm{~b}$ & $23.72 \mathrm{~b}$ & 15.66 \\
\hline \multicolumn{2}{c}{ LSD interaction at $\mathbf{p} \mathbf{0 . 0 5}$} & 8.47 & 7.78 & $\mathrm{Ns}$ \\
\hline
\end{tabular}

The critical role of 1000-grain weight on the yield potential of a grain crop cannot be disregarded because it expresses the enormity of seed development. The harvest index is an important parameter representing the photosynthetic efficiency of a crop in transformation of photosynthetase into economic yield. The results of transplanting and the priming effects on 1000-grain weight and harvest index were non-significant, as was the interaction between the treatments and blocks. Nevertheless, among treatments, the maximum 1000-grains weight was found in the 20-day-old primed seedlings, followed by 30-day-old primed seedlings (Table 4). 
M.B. JUNAID, A.A. ALDERFASI, I. AFZAL, H.A. WAJID, A. MAHMOOD

Table 3 - Effect of different seed invigoration techniques on agronomic and yield attributes

\begin{tabular}{|c|c|c|c|c|c|c|}
\hline \multicolumn{2}{|c|}{ Treatments } & $\begin{array}{l}\text { Plant } \\
\text { height } \\
\text { (cm) }\end{array}$ & $\begin{array}{c}\text { Cob } \\
\text { diameter } \\
(\mathbf{c m})\end{array}$ & $\begin{array}{c}\text { No. of } \\
\text { grains } \\
\text { per cob }\end{array}$ & $\begin{array}{l}\text { No. of rows } \\
\text { of grains per } \\
\text { cob }\end{array}$ & $\begin{array}{l}\text { No. of } \\
\text { cobs per } \\
\text { plant }\end{array}$ \\
\hline \multirow{3}{*}{ Non-prime } & Control & $119.7 c$ & $4.49 \mathrm{~b}$ & $760.02 b$ & $15.33 b c$ & 1.35 \\
\hline & $\begin{array}{l}20 \text { days } \\
\text { nursery }\end{array}$ & $129.9 b c$ & $4.34 b$ & $736.01 b$ & $15.00 \mathrm{c}$ & 1.34 \\
\hline & $\begin{array}{l}30 \text { days } \\
\text { nursery }\end{array}$ & $120 c$ & $4.38 b$ & $781.00 \mathrm{~b}$ & 16.33ab & 1.30 \\
\hline \multirow{3}{*}{ Prime } & Control & $139.8 b$ & $4.90 a$ & $831.33 b$ & $16.66 \mathrm{ab}$ & 1.61 \\
\hline & $\begin{array}{l}20 \text { days } \\
\text { nursery }\end{array}$ & $162.69 a$ & $4.95 a$ & $959.67 a$ & $17.33 a$ & 1.54 \\
\hline & $\begin{array}{l}30 \text { days } \\
\text { nursery }\end{array}$ & $133.6 \mathrm{bc}$ & $4.90 a$ & $825.00 \mathrm{~b}$ & $16.00 \mathrm{bc}$ & 1.47 \\
\hline \multicolumn{2}{|c|}{$\begin{array}{l}\text { LSD interaction } \\
\text { at } p \geq 0.05\end{array}$} & 31.2 & 0.25 & 77.50 & 1.29 & NS \\
\hline
\end{tabular}

Table 4 - Effects of different seed invigoration techniques on agronomic and yield attributes

\begin{tabular}{|c|c|c|c|c|c|c|}
\hline \multicolumn{2}{|c|}{ Treatments } & $\begin{array}{l}1000 \text {-grain } \\
\text { weight }(\mathrm{g})\end{array}$ & $\begin{array}{c}\text { Stover } \\
\text { yield } \\
\left(\mathrm{t} \mathrm{ha}^{-1}\right)\end{array}$ & $\begin{array}{c}\text { Grain } \\
\text { yield } \\
\left(\mathrm{t} \mathrm{ha}^{-1}\right)\end{array}$ & $\begin{array}{c}\text { Biologic } \\
\text { al yield } \\
\left(\mathrm{t} \mathrm{ha}^{-1}\right)\end{array}$ & $\begin{array}{c}\text { Harvest } \\
\text { index } \\
(\%)\end{array}$ \\
\hline \multirow{3}{*}{ Non-prime } & Control & $224.56 c$ & $4.23 b$ & $4.13 d$ & $10.10 d$ & 40.89 \\
\hline & $\begin{array}{l}20 \text { days } \\
\text { nursery }\end{array}$ & $243.00 \mathrm{~b}$ & $4.40 \mathrm{~b}$ & $6.2 b$ & $14.36 \mathrm{bc}$ & 43.18 \\
\hline & $\begin{array}{l}30 \text { days } \\
\text { nursery }\end{array}$ & 257.70ab & $4.67 a b$ & $5.2 \mathrm{c}$ & $13.00 \mathrm{c}$ & 40.00 \\
\hline \multirow{3}{*}{ Prime } & Control & $239.90 b$ & $5.93 a$ & 6.39ab & 15.63ab & 40.88 \\
\hline & $\begin{array}{l}20 \text { days } \\
\text { nursery }\end{array}$ & $291.63 a$ & $5.97 a$ & $7.08 \mathrm{a}$ & $17.40 \mathrm{a}$ & 40.69 \\
\hline & $\begin{array}{l}30 \text { days } \\
\text { nursery }\end{array}$ & $265.50 a b$ & 5.53ab & $6.85 a b$ & $17.03 a$ & 40.22 \\
\hline \multicolumn{2}{|c|}{$\begin{array}{l}\text { LSD interaction } \\
\text { at } p \geq 0.05\end{array}$} & 22.07 & 0.65 & 0.76 & 1.84 & NS \\
\hline
\end{tabular}

The effect of treatments and blocks on stover and grain yield was non-significant and significant, respectively. Biological yield was significantly affected by treatments, but not by blocks. The interaction effect between treatments and blocks were significant in stover, grain, and biological yield (Table 4). The interaction results show that maximum stover, grain, and biological yield were observed in 20-day-old primed seedlings, whereas highest stover yield was statistically at par with that of control primed seeds and minimum stover yield observed under control non-primed seeds, which was statistically similar to that 
of 20 days' non-primed seedlings. The maximum grain yield was found in the 30-day-old primed seedlings and control primed seeds, which were statistically similar. The minimum grain and biological yield were found in the control non-primed seeds and 30-day-old primed seedlings (Table 4).

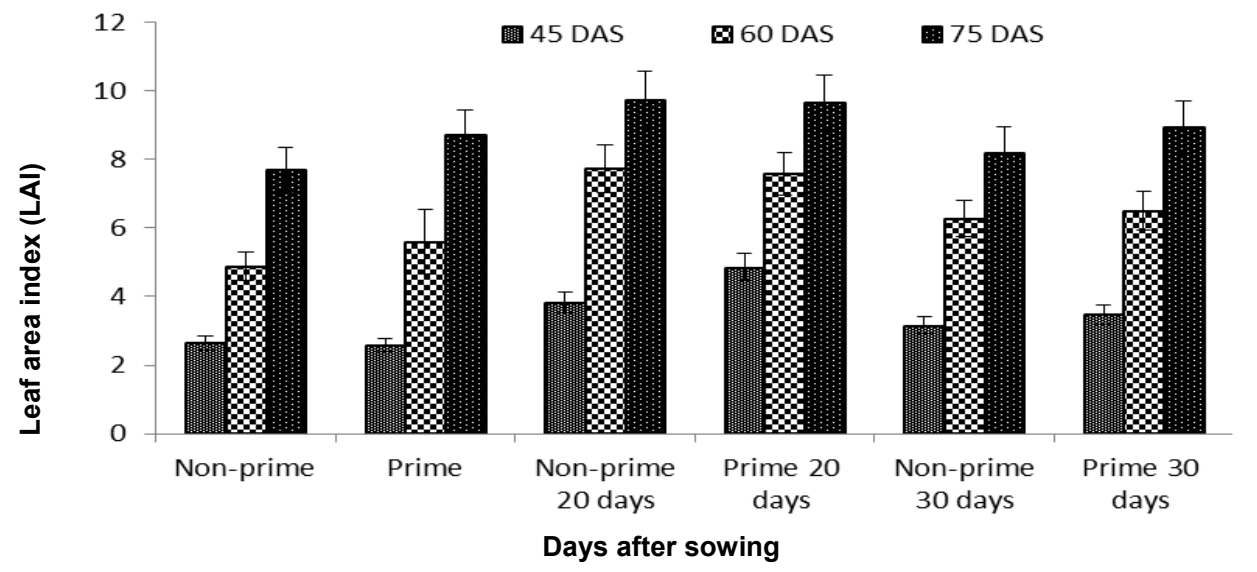

Figure 6 - Effects of different seed invigoration techniques on leaf area index (LAl)

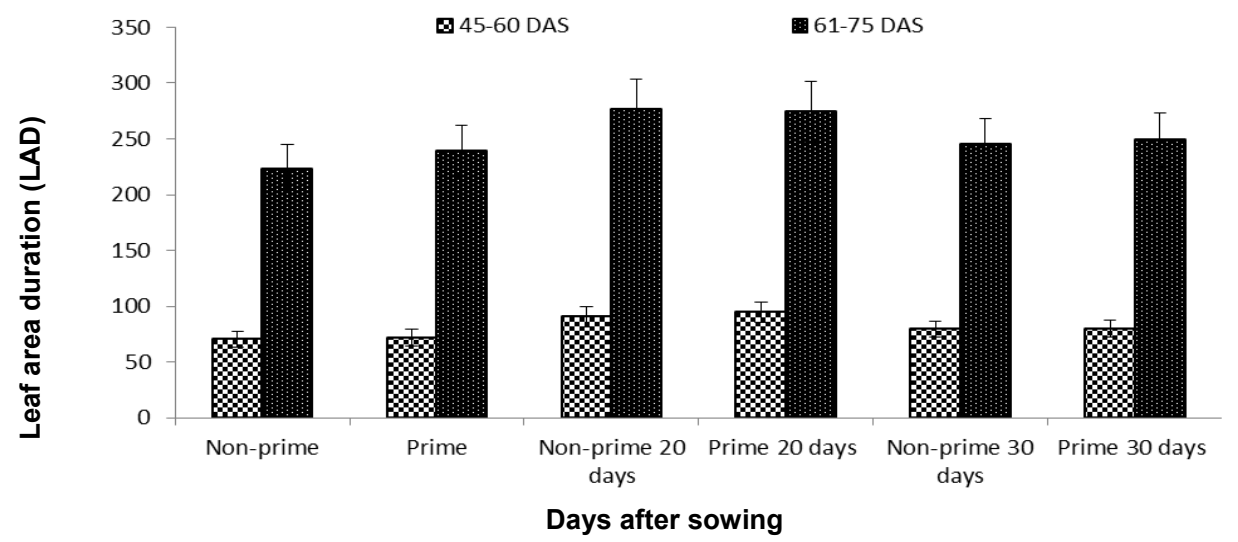

Figure 7 - Effects of different seed invigoration techniques on leaf area duration (LAD)

\section{Grain quality parameters}

The effects of the treatments were significant on grain protein contents, but not on grain oil contents, while the interaction between treatments and blocks on grain protein and oil content was significant and non-significant, respectively (Fig. 9). The maximum grain protein content was found in 30-day-old primed seeds, which was statistically like that of the control primed seeds. Minimum grain protein content was observed in control non-primed seeds (Fig. 9). 
Maximum grain oil content was observed in 20-day-old primed (MLE) seedlings, which was statistically like that of 30-day-old primed (MLE) seedlings and control primed seeds.
Minimum grain oil content was found in control non-primed seeds, which was statistically like 30 and 20-dayold non-primed seedlings (Fig. 9).

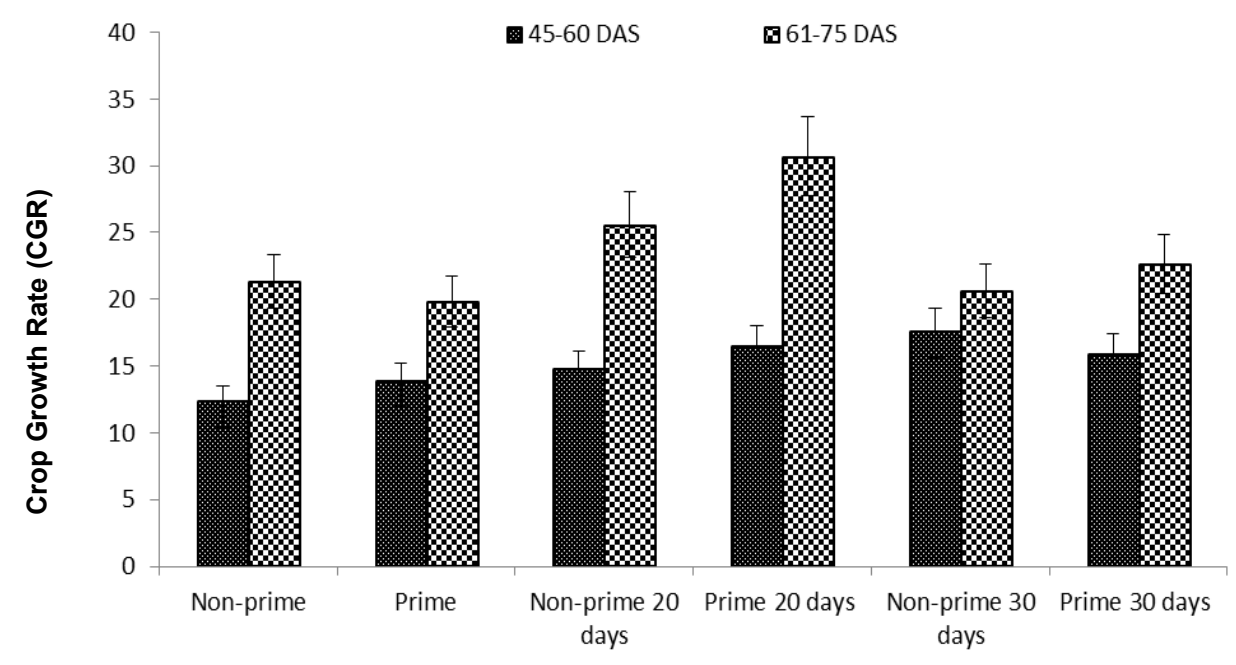

Days after sowing

Figure 8 - Effects of different seed invigoration techniques on crop growth rate (CGR)

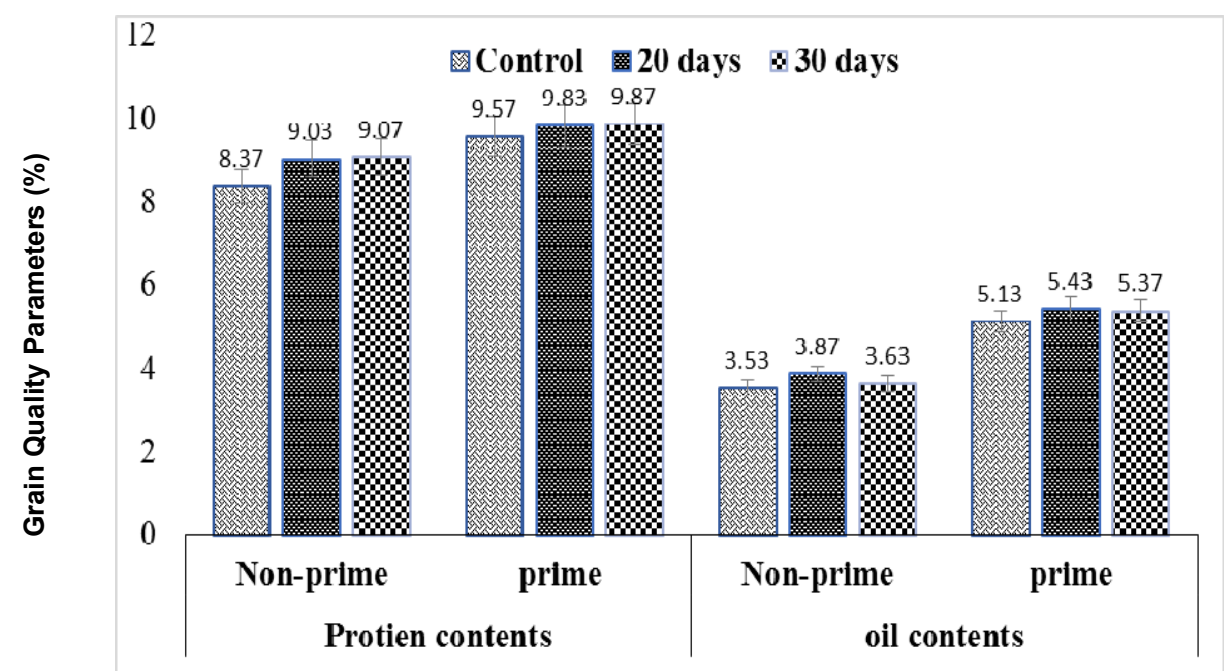

Figure 9 - Effects of different seed invigoration techniques on grain quality 


\section{DISCUSSION}

Seed invigoration techniques are used to reduce germination time, harmonize germination, improve emergence rate, and better seedling stands in many field crops, including maize fields (Afzal et al., 2006, 2008; Farooq et al., 2008b; Carbonell et al., 2000; Răcuciu et al., 2008). Seed priming predicted that uniform germination leads to the production of vigorous seedlings with high chlorophyll contents in leaves. Early emergence, as indicated by lower METs in 20 and 30-day-old primed seeds, may be due to the faster production of germination metabolites (Lee and Kim, 2000; Basra et al., 2005). The reason for the improved stand establishments in primed seeds is that the MLE modulates the cell membrane structure causing increases in their permeability and ion transport in the ion channels, ultimately affecting metabolic pathway activities leading to boosted germination. Decreases in emergence count due to control non-primed direct seeding was the result of temperature fluctuations, which ultimately affects seed health via chilling injury (Fig. 5). The disruption of the circadian regulation of metabolism and insufficient antioxidant defense are thought to cause chilling sensitivity (Foyer et al., 2002).

This study revealed that chilling stress increased mean emergence time and reduced the final emergence percentage in nursery grown seedlings, whereas it increased the final emergence percentage and decreased the mean emergence time of directly sown seeds primed with MLE. Seedlings which had lower MET were considered to have a higher vigor. Similarly, increased germination, speed of germination, emergence, vigor index, and seedling vigor in maize seeds subjected to 20-day-old primed seedlings exposure also support current findings (Vashisth and Nagarajan, 2007). Like the findings of Florez et al. (2007), we found better germination rates in maize seeds grown from primed seedlings. The early emergence of the primed seed may be due to the completion of pre-germination metabolic activities responsible for regulation of biochemical process during germination (Ashraf and Foolad, 2005). Maize yield increased because of the improved stand establishment when using 20-day-old transplanted seedlings primed with MLE (Harris et al., 2007). MLE priming promoted root growth and nutrient uptake by healthy roots (Afzal et al., 2008 and Basra et al., 2011). Primed seeds might enhance the growth of spring maize as indicated by observations of growth analysis (Figs. 2, 3 and 4). This may also be accredited to the fact that seed priming triggers many biochemical changes, such as enzyme activation, starch hydrolysis, and dormancy breaking in seeds. These processes are 
needed to start the germination process; thus, primed seeds are more effective than non-primed (Bakhtavar et al., 2015).

Increases in the number of leaves, days taken to $50 \%$ tasseling, silking, and physiological maturity, days taken from emergence to anthesis and tasseling to silking, LAI, LAD, and CGR from seeds of spring maize might be the result of healthy and improved vigorous seedlings (Figs. 2, 3 and 4), which gave them an energetic start. Improved maturity days in plants raised from primed seeds also seemed to result in improved leaf area duration (Fig. 3), which resulted in enhanced net assimilation rates in maize. Poor growth and development of control, or direct seeding, and non-primed plants might be due to lower temperatures, which drastically affected photosynthesis in maize (Haldimann et al., 1996). In 20-day-old primed seedlings, when the conditions were suitable for growing, crop growth rate was improved because of the strong and energetic start from vigorous seedlings, which resulted in an improved LAI, and thus, improved crop growth rates. Moreover, the temperature was quite high during the reproductive stage in 30-day-old seedlings, face more days under green house at higher temperature than field conditions that reduced the crop growth (Smith, 1996).

Seed priming techniques resulted in vigor enhancement in maize (Farooq et al., 2008a) and the field performance of vigorous seeds is much better than that of less vigorous seeds. This suggests that vigorous seedlings of seeds primed with MLE resulted in a higher number of leaves per plant, more days taken to $50 \%$ tasseling and silking, physiological maturity, emergence to anthesis, tasseling to silking, and increased LAI, LAD, and CGR levels than in non-primed seeds. The same characteristics were higher in transplanted maize plants than the control (Tables 1 and 2 and Figs. 2, 3 and 4). Similarly, previous studies found that seed priming with MLE improves maize establishment in cool environments (Afzal et al., 2012). These results are like those of Anjorin et al. (2010), who reported that MLE improved the growth rate of maize crops and increased the leaf area and photosynthetic rates as mineral composition. The MLE also positively influences the physiological processes that occur within the plant. Yasmeen et al. (2012) found that MLE improved the leaf area of late sown wheat.

The data in this study (Table 1) revealed that in transplanted maize seedling the days to tasseling and silking came earlier than in directly planed maize. These findings are like those of Ying et al. (1998), who found that transplanted crops attained silking 10-14 days earlier than directly planted crops. This study confirms that crop growth can be improved by priming with MLE in spring maize. The application of MLE for priming improves the growth stages, i.e. knee height, tasseling, and grain filling 
resulted in heavier and bold grains, and increased grain and biological yield (Yasmeen et al. 2012). Fuglie (1999) found that the presence of growth promoting substances in MLE extended seasonal leaf area duration, grain filling period, and yield attributes, which increases economic and biological yield in wheat crop.

Our results indicate that chilling stress affected all the agronomic traits (grain yield and yield contributing factors) of spring planted maize (Tables 3 and 4). However, seed priming with MLE successfully induced the chilling tolerance in maize plants (Farooq et al., 2008a). These results are consistent with our findings that agronomic related parameters performed better in primed seeds than non-primed and control seeds due to early emergence and higher relative growth rates than nonprimed and control treatments. Nursery growing helps maize crops to grow early, which prevents plants from having to face higher temperatures during the reproductive stage. Sudden temperature increases lead to tassel blast in maize crops (Smith, 1996). Conditions of continuous higher temperatures and low rain fall reduced grain filling processes and ultimately reduced grain yield (Johnson and Herrero, 1982).

The plant height $(\mathrm{cm})$ and cob diameter $(\mathrm{cm})$ increase under 20 days' primed seedlings (Table 3). The earlier stand establishment was boosted, and this played an important role in later growth stages of maize plants and ultimately produced better yield (Nagar, 1998). These results are like those of Price (1985), who predicted that the use of MLE for priming increased maize height and other agronomic characters and increased yield by $16 \%$ from $60-130 \%$ sacks per hectare. Seeds treated with MLE produced more and larger fruits leading to a higher yield at final harvest. The exogenous application of MLE in maize increased yield by 25-30 \% (Foidl et al., 2001). Furthermore, Fanadzo et al. (2009) said that the transplants produced longer cobs than directly planted maize. The number of cobs per plants, grains per row, grains per cob, and 1000-grains weight (g) was significantly increased with MLE priming (Table 4). The transplanting of maize seedling produced higher yield than the direct planting of maize (Dale and Drennan, 1997). Thus, in this study, seed priming was found to be significantly more effective at improving the yield and yield components of maize seeds than untreated maize seeds. Primed seed treatments contributed significantly to improving the grain quality, i.e. seed protein and oil contents (Fig. 9). Maximum values for these quality parameters were recorded for 20 and 30-day-old and control primed treatments and compared to those of non-primed treatments. Truong et al. (2013) reported that growth promoting substances present in MLE boosted crop growth and photosynthetic rates and ultimately more photo assimilates were translocated towards grain 
increasing its oil contents. The lower protein content in the grains after MLE priming is the fact in developing seed more photosynthate were translocated towards lipid biosynthesis. Similarly, inverse relation for oil and protein contents increased.

\section{CONCLUSIONS}

This study suggests that 20-day-old seeds grown in nurseries, primed with MLE (3\%) are effective not only at improving seedling establishment, but also the performance of maize under early, as well as optimum sowing conditions. Thus, two these seeds can be used in the field to improve the germination in hybrid maize under adverse climatic conditions.

Acknowledgments. The authors extend their appreciation to the Deanship of Scientific Research at King Saud University for funding the current work. The authors thank the Deanship of Scientific Research and RSSU at King Saud University for their technical support.

\section{REFERENCES}

Abedullah, Mahmood, N., Khalid, M. \& Kouser, S. (2009). The role of agricultural credit in the growth of livestock sector: a case study of Faisalabad. Pakistan Vet.J., 29(2): 81-84.

Afzal, I., Basra, S.M.A., Ahmad, N., Cheema, M.A., Warraich, E.A. \& Khaliq, A. (2002). Effect of priming and growth regulator treatments on emergence and seedling growth of hybrid maize (Zea mays L.). Int.J.Agric.Biol, 4(2): 303-306.

Afzal, I., Basra, S.M.A., Hameed, A. \& Farooq, M. (2006). Physiological enhancements for alleviation of salt stress in wheat. Pak.J.Bot, 38(5): 1649-1659.

Afzal, I., Basra, S.M.A., Shahid, M., Farooq, M. \& Saleem, M. (2008). Priming enhances germination of spring maize (Zea mays L.) under cool conditions. Seed SciTechnol., 36(2): 497-503, DOI: 10.15258/sst. 2008.36.2.26

Afzal, I., Hussain, B., Basra, S. \& Rehman, H. (2012). Priming with moringa leaf extract reduces imbibitional chilling injury in spring maize. Seed Sci.Technol., 40(2): 271-276, DOI:10.15258/sst.2012.40. 2.13

Ajouri, A., Asgedom, H. \& Becker, M. (2004). Seed priming enhances germination and seedling growth of barley under conditions of $\mathrm{P}$ and $\mathrm{Zn}$ deficiency. J.Plant Nutr.Soil Sci., 167(5): 630-636, DOI: 10.1002/jpln. 200420425

Aroca, R., Vernieri, P., Irigoyen, J.J., Sánchez-Díaz, M., Tognoni, F. \& Pardossi, A. (2003). Involvement of abscisic acid in leaf and root of maize (Zea mays L.) in avoiding chilling-induced water stress. Plant Sci, 165(3): 671-679, DOI: 10.1016/S0168-9452(03)00257-7

Ashraf, M. \& Foolad, M.R. (2005). Pre-sowing seed treatment - a shotgun approach to improve germination, plant growth, and crop yield under saline and non-saline conditions. Adv.Agron., 88: 223-271, DOI: $\quad 10.1016 / S 0065-2113(05) 8800$ 6-X.

Badran, M.S.S. (2001). Effect of transplanting and seedling age on grain yield and its components of some maize cultivars. Alexandria J.Agric.Res., 46(2): 47-56. 
Bakhtavar, M.A., Afzal, I., Basra, S.M.A., Ahmad, A-u-H \& Noor, M.A. (2015). Physiological strategies to improve the performance of spring maize (Zea mays L.) planted under early and optimum sowing conditions. PloS ONE, 10(4): e0124441, DOI: 10.1371/journal. pone.0124441

Basra, S., Farooq, M., Tabassam, R. \& Ahmad, N. (2005). Physiological and biochemical aspects of presowing seed treatments in fine rice (Oryza sativa L.). Seed Sci.Technol., 33(3): 623-628, DOI: 10.15258/sst. 2005.33.3.09

Basra, S., Iftikhar, M.N. \& Afzal, I. (2011). Potential of moringa (Moringa oleifera) leaf extract as priming agent for hybrid maize seeds. Int.J.Agric.Biol., 13(6): 10061010.

Basu, S. \& Sharma, S. (2003). Effect of transplanting on vegetative, floral and seed characters of maize (Zea mays) parental lines in springsummer season. Indian J.Agr.Sci., 73(1): 44-48.

Bradford, K.J. (1986). Manipulation of seed water relations via osmotic priming to improve germination under stress conditions. HortScience, 21: 1105-1112.

Carbonell, M.V., Martinez, E. \& Amaya, J. M. (2000). Stimulation of germination in rice (Oryza sativa L.) by a static magnetic field. Electro Magnetobiol., 19(1): 121-128, DOI: 10.1081/JBC-100100303

Dale, A. \& Drennan, D. (1997). Transplanted maize (Zea mays) for grain production in southern England. III. Effects of plant growth regulator treatments on maize transplant morphology. J.Agric.Sci., 128(1): 45-50, DOI: 10.1017/S00 21859696003899

Ellis, R.A. \& Roberts, E.H. (1981). The quantification of ageing and survival in orthodox seeds. Seed Sci.Technol., 9: 373-409.
Fanadzo, M., Chiduza, C. \& Mnkeni, P.N. (2009). Comparative response of direct seeded and transplanted maize (Zea mays L.) to nitrogen fertilization at Zanyokwe irrigation scheme, Eastern Cape, South Africa. Afr.J.Agric.Res., 4(8): 689-694.

Farooq, M., Basra, S.M.A., Rehman, H., \& Saleem, B.A. (2008a). Seed priming enhances the performance of late sown wheat (Triticum aestivum L.) by improving chilling tolerance. J.Agron. Crop Sci., 194(1): 55-60, DOI: 10.1111/j.1439037X.2007.00287.X

Farooq, M., Basra, S.M.A., Wahid, A., Cheema, M.A. \& Khaliq, A. (2008b). Physiological role of exogenously applied glycinebetaine to improve drought tolerance in fine grain aromatic rice (Oryza sativa L.). J.Agron. Crop Sci., 194(5): 325-333, DOI: $10.1111 / \mathrm{j} .1439-037 X .2008 .003$ 23. $x$

Farooq, M., Aziz, T., Wahid, A., Lee, D.J., \& Siddique, K.H.M. (2009). Chilling tolerance in maize: agronomic and physiological approaches. Crop Pasture Sci., 60(6): 501-516, DOI: 10.1071/CP 08427

Flórez, M., Carbonell, M. V. \& Martínez, E. (2007). Exposure of maize seeds to stationary magnetic fields: effects on germination and early growth. Environ.Exp.Bot., 59(1): 68-75, DOI: 10.1016/j.envexpbot.2005.10.006

Foidl, N., Makkar, H.P.S. \& Becker, K. (2001). Potentiel de Moringa oleifera en agriculture et dans l'industrie. Potentiel de développement des produits de Moringa. Dar es-Salaam, Tanzanie.

Foyer, C.H., Vanacker, H., Gomez, L. D., \& Harbinson, J. (2002). Regulation of photosynthesis and antioxidant metabolism in maize leaves at optimal and chilling temperatures. Plant Physiol.Biochem., 40(6-8): 659-668, DOI: 10.1016/S0981-9428 (02)01425-0 
Fuglie, L.J. (1999). The miracle tree: Moringa oleifera, natural nutrition for the tropics. Church World Service, Dakar, 68.

Gai, Y.P., Li, X., Ji, X., Wu, C., Yang, G. \& Zheng, C. (2008). Chilling stress accelerates degradation of seed storage protein and photosynthetic protein during cotton seed germination. J. Agron. Crop Sci., 194(4): 278-288, DOI: 10.1111/j. 1439-037X.2008.00311.x

Ghiyasi, M., Myandoab, M.P., Tajbakhsh, M., Salehzade, H. \& Meshkat, M.V. (2008). Influence of different osmopriming treatments on emergency and yield of maize (Zea mays L.). Res.J.Biol.Sci., 3(12): 1452-1455.

Grossman, S. \& Leshem, Y.Y. (1978). Lowering of endogenous lipoxygenase activity in Pisum sativum foliage by cytokinin as related to senescence. Physiol. Plant., 43(4): 359-362, DOI: 10.11 11/j.1399-3054.1978.tb01594.x

Haldimann, P., Fracheboud, Y. \& Stamp, P. (1996). Photosynthetic performance and resistance to photoinhibition of Zea mays L. leaves grown at sub-optimal temperature. Plant Cell Environ., 19(1): 85-92, DOI: 10.1111/j.13653040.1996.tb00229.x

Harris, D., Rashid, A., Miraj, G., Arif, M. \& Shah, H.U. (2007). 'On-farm'seed priming with zinc sulphate solution a cost-effective way to increase the maize yields of resource-poor farmers. Field Crops Research, 102(2): 119-127, DOI: 10.1016/j.fcr. 2007.03.005

Hunt, R. (1978). Growth analysis, individual plants. Plant Growth Analysis,

Jahn, S.A.A. (1989). Moringa oleifera for food and water purification-selection of clones and growing of annual short stem. Entwicklung und Landlicher Raum, 23(4): 22-25.

Janowiak, F., Luck, E. \& Dörffling, K. (2003). Chilling tolerance of maize seedlings in the field during cold periods in spring is related to chilling-induced increase in abscisic acid level. J.Agron. Crop Sci., 189(3): 156-161, DOI: 10.1046/j. 1439-037X.2003.00027.x

Johnson, R.R. \& Herrero, M.P. (1982). Corn pollination under moisture and high temperature stress. Proceedings of the annual corn and sorghum industry research conference ASTA, Corn and Sorghum Division, Corn and Sorghum Research Conference.

Lee, S.-S. \& Kim, J.-H. (2000). Total sugars, $\alpha$-amylase activity, and germination after priming of normal and aged rice seeds. Korean J. Crop Sci., 45(2): 108-111.

Mok, M. C. (1994). Cytokinins and plant development. An Overview. In: Mok, D.W.S. and Mokeds, M.C.(Eds.), Cytokinin: Chemistry, Activity and Function, CRC Press, Boca Raton, 155-166.

Nagar, R., Dadlani, M. \& Sharma, S. (1998). Effect of hydropriming on field emergence and crop growth of maize genotypes. Seed Sci.Res., 26: 1-5.

Olson, M.E. \& Carlquist, S. (2001). Stem and root anatomical correlations with life form diversity, ecology, and systematics in Moringa (Moringaceae). Bot.J.Linn.Soc., 135(4): 315-348, DOI: 10.1111/j. 1095-8339.2001.tb00786.x

Price, M.L. (1985). The Moringa tree: Revised in 2000 by Kristin Davis, pp. 1-14.

Răcuciu, M., Creangă, D. \& Horga, I. (2008). Plant growth under static magnetic field influence. Rom.J. Phys, 53(1-2): 353-359.

Rehman, H.U., Basra, S.M.A. \& Farooq, M. (2011). Field appraisal of seed priming to improve the growth, yield, and quality of direct seeded rice. Turk.J.Agric.For., 35(4): 357-365.

Smith, V. (1996). Enhancement of snap bean emergence by Gliocladium 


\section{MORINGA LEAF EXTRACTS AND TRANSPLANTATION OF MAIZE IMPROVES CHILLING TOLERANCE}

virens. HortSci., 31(6): 984-985, DOI: 10.21273/HORTSCI.31.6.984

Sowiński, P., Rudzińska-Langwald, A., Adamczyk, J., Kubica, I. \& Fronk, J. (2005). Recovery of maize seedling growth, development and photosynthetic efficiency after initial growth at low temperature. J. Plant Physiol., 162(1): 67-80, DOI: 10.1016/j.jplph.2004.03.006

Steel, R.G.D., Torrie, J.H. \& Dickey, D. (1997). Principles and procedures of statistics: a biometrical approach., 3rd ed. (McGraw-Hill: New York).

Truong, Q., Koch, K., Yoon, J.M., Everard, J.D. \& Shanks, J.V. (2013). Influence of carbon to nitrogen ratios on soybean somatic embryo (cv. Jack) growth and composition. J.Exp.Bot., 64(10): 2985-2995, DOI: 10.1093/jxb/ert138

Vashisth, A. \& Nagarajan, S. (2007). Effect of pre-sowing exposure to static magnetic field of maize (Zea mays L.) seeds on germination and early growth characteristics. Pusa Agrisci, 30: 48-55.

Verheul, M.J., Van Hassel, P.R. \& Stamp, P. (1995). Comparison of maize inbred lines differing in low temperature tolerance: effect of acclimation at suboptimal temperature on chloroplast functioning. Ann.Bot., 76(1): 7-14, DOI: 10.1006/anbo.1995.1072

Watson, D.J. (1947). Comparative physiological studies on the growth of field crops: I. Variation in net assimilation rate and leaf area between species and varieties, and within and between years. Ann.Bot., 11(41): 41-76, DOI: 10.1093/ oxfordjournals.aob.a083148

Yasmeen, A., Basra, S.M.A., Ahmad, R. \& Wahid, A. (2012). Performance of late sown wheat in response to foliar application of Moringa oleifera Lam. leaf extract. Chil.J.Agr.Res., 72(1): 92-97.

Ying, J., Peng, S., He, Q., Yang, H., Yang, C., Visperas, R.M. \& Cassman, K.G. (1998). Comparison of high-yield rice in tropical and subtropical environments: I. Determinants of grain and dry matter yields. Field Crop.Res., 57(1): 71-84, DOI: $\quad 10.1016 / S 0378-4290(98) 000$ $77-X$ 